KARSAI Judit

\title{
ÁLDÁS VAGY ÁTOK?
}

\section{A MAGÁNTŐKE-BEFEKTETÉSEK HATÁSA A GAZDASÁGRA}

\begin{abstract}
A gazdasági és politikai élet szereplói körében már régóta világszerte vita folyik arról, hogy a magántôke-befektetések ${ }^{1}$ milyen hatást gyakorolnak a gazdaságra. A vita fókuszában a magántóke-befektetéseknek csak egy szúkebb csoportja áll, nevezetesen a hitel igénybevételéból történố kivásárlások (Leveraged Buyout, LBO) hatása. Miközben a cégek fejlôdésének korai fázisában történó kockázatitóke-befektetések pozitív hatását senki sem kérdôjelezi meg, a válság közepette különös élességgel vetôdik fel egy kérdés. Vajon a magántớke valóban olyan tulajdonosi modell, amely képes a megvásárolt cégek fenntartható javulását előidézni, avagy csupán egy egyszerú pénzügyi konstrukció, esetleg mindkettô. A kérdés tehát valójában az, hogy a magántốke a kivásárlásra kerülố cégek részvényeire tett, hitellel kiegészített ajánlata révén, a cégeket szakszerúen kiválasztva és menedzselve jut-e a tôzsdei befektetésekhez képest magasabb hozamokhoz, avagy csupán egy pénzügyi trükkról van szó, amely az adókedvezmények kihasználásával és a cégekben lévố vagyon kiszivattyúzásával csak a jövedelmeket rendezi át ${ }^{2}$.
\end{abstract}

Kulcsszavak: magántóke-befektetések, magántốke, kockázati tóke

A magántőke-befektetésekkel foglalkozó publikációk jelentős része világszerte lobbiérdekeket szolgál. A tudományos igényú kutatások összességében nem igazolják, hogy magántóke-befektetốk a portfoliocégek megkopasztásával zsebelnének be óriási hozamokat. Nem támasztják alá azt sem, hogy a kivásárlások negatív hatást gyakorolnának az érintett szektorok növekedésére vagy versenyképességére, illetve, hogy instabillá tennék magát a pénzügyi és gazdasági rendszert. Nem igazolják az állások megszüntetésére vonatkozó aggodalmakat, igaz azt sem, hogy a kivásárlások erôs foglalkoztatásnövekedéssel járnának. Az elemzések a magántốke által finanszírozott cégeknél viszonylag magasabb munkatermelékenységet találtak. A bérek esetében pedig a magántóke-finanszírozás semleges hatását állapították meg.

\section{A magántóke-befektetés modellje}

A magántóke-befektetések gazdasági hatásának áttekintése annak az alapkérdésnek az eldöntésében segít, hogy a magántóke maga is teremt-e értéket, avagy csupán az értékek elosztását változtatja meg a gazdaság szereplői között. A válasz a magántôke-finanszírozási ágazat múködési módját jelentő modell elónyeinek és hátrányainak mérlegelésén múlik.

A magántốke-befektetốk tulajdonosi modellje lényegében egy befektetési stratégián és az ehhez kapcsolódó szerződésen alapul (Strömberg, 2009). A befektetési stratégia rendszerint tôzsdén nem jegyzett, ritkábban tốzsdei vállalkozások részvényeinek megvásárlását takarja. A befektetést követôen a szóban forgó cégek részvényei nyilvánosan nem jegyezhetók. A befektetés célja a portfólióba beválasztott cégek fejlesztése és/vagy értékének növelése, eszköze pedig a menedzseri döntések ellenőrzése, a felelősségi körök pontos meghatározása és megfelelő ösztönzési rendszer kialakítása.

A magántóke üzleti modellje a befektetók és a menedzserek érdekeinek sokrétú összehangolásával - így az ösztönzés, az ellenôrzés és a hitel kombinációjával - igyekszik hozzájárulni a cégek teljesítményének javulásához. Az alapok befektetóinek és kezelóinek érdekeit egy olyan szerződésrendszer biztosítja, amely az alapkezelốk számára a kezelt tóke értékének bizonyos hányadában meghatározott alapkezelói díjat állapít meg. Ezenfelül az alapok kezelői egy meghatározott hozamküszöb elérését követôen maguk is részesednek az alap által elért hozamokból is, ami magasabb hozam 
elérésére irányuló ösztönzést jelent a számukra. A befektetốk mellett az alapkezelő́k kis hányadban maguk is befektetnek az alapokba, s ezáltal érdekeltté válnak az alapok nyereséges múködésében.

A zömmel intézményi befektetốk tốkéjéből, meghatározott idôtartamra felállított, s kezelési költség és sikerdíj fejében professzionális alapkezelő́k által múködtetett magántő́ke-alapok rendszerint ellenórzó szerepet biztosító tulajdoni hányadot szereznek a kivásárolt cégekben. Az alapokba tôkét fektetô intézményi befektetốk az alapok tanácsadó testületein vagy befektetési bizottságain keresztül kapnak áttekintést az alapok múködéséról, emellett az alapok indulásakor, illetve meghatározott időszakonként részletes auditált jelentést is kapnak az alapok kezelőitől. Az alapok indulásakor a befektetốk kötelezettséget vállalnak egy meghatározott összeg nyújtására, melyet az alapok kezelői a befektetések ütemében hívnak le. A magántốkealapok befektetối az odaígért tókét az alapok életének lejártáig nem vonhatják vissza. A magántốke-alapok a befektetések hasznát akkor realizálják, amikor az alapok portfoliojában lévő cégekben birtokolt részesedésektól megválnak. Az alapokra rendszerint tízéves élettartam jellemző, melynek leteltével az alap teljes tókéjét az alapkezelók visszajuttatják a befektetôkhöz.

\section{A magántôkepiac fejlôdése és jelentôsége}

A magántôke-befektetések gazdaságra gyakorolt pozitív vagy negatív hatásának megítéléséhez ismerni kell annak hatókörét, azaz abszolút és relatív nagyságát. A statisztikai adatok egyértelmúen alátámasztják, hogy a magántốke-finanszírozás az elmúlt tíz évben világszerte egyre fontosabb mechanizmusává vált a cégek gyors és radikális restrukturálásának. Ugyanakkor a magántő́ke tevékenység közelmúltbeli növekedése és a pénzügyi rendszer néhány szegmensében játszott fontossága ellenére a magántókeipar csak viszonylag kis hányadát fedi le a vállalatok finanszírozásához kapcsolódó gazdasági tevékenységnek.

A magántőke-ágazat jelentőségének növekedésére utal, hogy az elmúlt években egyaránt drámai növekedés jellemezte a magántóke-befektetoók által felvásárolt cégek számát és a magántőke-befektetések értékét. Az 1970 és 2007 között világszerte végrehajtott, több mint 20 ezer magántőke-befektetési ügyletre kiterjedő eddigi legátfogóbb vizsgálat (Lerner - Gurung, 2008) adatai szerint a hitel igénybevételével kivásárolt cégek értéke 3600 milliárd dollárt ért el, melyból 2700 milliárd dollár értékú cégvásárlásra 2002 és 2007 között került sor. A magántőke-befektetők tulajdonában lévő cégek száma is erőteljesen emelkedett. 1970 óta min- den évben számottevően több hitellel történő kivásárlásra került sor, mint ahány ilyen cégból a befektetók kiléptek. Így 2007 elejére a világon már közel 14 ezer cég volt magántôke-befektetốk (rész)tulajdonában, holott 2000-ben e cégek száma még csak ötezer, a kilencvenes évek közepén pedig mindössze kétezer volt (Lerner - Gurung, 2008). Világszerte mintegy 25003000 magántóke-befektető alap múködik, beleértve a klasszikus kockázatitóke-alapokat. Túlnyomó részük, közel 2000 intézmény az Egyesült Államokban található (PEI, 2007).

Az IFSL (2009) legfrissebb becslése szerint 2008ban közel 190 milliárd dollár értékú magántôke-befektetésre került sor világszerte, ami a válság hatására 40\%-kal esett vissza az elôzó évi közel 320 milliárd dollár értékú befektetési volumenhez képest. A befektetések 25\%-át az Egyesült Államokban, 40\%-át a válság által akkor még kevésbé sújtott Európában hajtották végre. A magántốkések által befektetési céllal összegyưjiött tóke értéke 2008-ban 450 milliárd dollárt tett ki, ami negyvenmilliárd dollárral volt kevesebb az előző évben általuk összegyújtött tốkénél. 2008-ban a befektetési céllal gyújtött tốke közel kétharmada (64\%) Amerikából, negyede pedig Európából érkezett a magántóke-alapokhoz. A magántókealapok által kezelt teljes vagyon, azaz a befektetésre rendelkezésükre álló tóke és a portfolioikban lévő cégek vagyona együtt 2500 milliárd dollár értéket képviselt 2008-ban, ami 15\%-kal haladta meg az előző évi nagyságrendet. Elsôsorban a 2006 és 2008 első felében gyújtött igen jelentős összegú tốkének köszönhetően a magántôkke-befektetốk 2008-ban világszerte közel ezermilliárd dollár értékú befektethetố tő́kével rendelkeztek, azaz vagyonuk közel $60 \%$-a feküdt a még el nem adott cégekben (IFSL, 2009).

A magántốke-befektetések nagyságrendjének megítélését elősegíti, ha méretét a nyilvános részvénypiacokon jegyzett részvények értékéhez viszonyítjuk. Az erre vonatkozó becslések szerint a magántókealapok által ellenôrzött tốkeérték az összes nyilvános tókepiacon jegyzett részvény tókeértékének 2-3\%-át teszi ki (Kehoe - Palter, 2009; Davis és társai, 2008). További támpontot nyújt az ügyletek jelentôségének felméréséhez, hogy 2006-ban például a tốzsdén elsố ízben megjelenő cégek (IPO) harmadát képviselték magántôke-hátterú cégek (Jensen, 2007). További adalék, hogy 2008-ban világszerte az M\&A ügyletek 7\%-a kötôdött a magántôkésekhez, s ez 2001 óta a legalacsonyabb arány volt. Különösen 2006-hoz képest esett vissza jelentősen a magántốke-befektetôk által finanszírozott ügyletek részaránya a vállalatfelvásárlások körében, amikor ezen ügyletek az összes ügylet értékének ötödét 
adták (IFSL, 2009). A magántóke-befektetések volumenének közelmúltban tapasztalt jelentôs növekedése ellenére az európai magántóke-befektetések éves értéke az Európai Unió GDP-jének még a fél százalékát sem érte el. Az évtized elején mért, közel 0,25\%-os arány a 2008-as válság idején 0,4\% feletti hányadot mutatott, ami lényegében az évtized közepén mért aránynak felel meg (EVCA, 2009).

\section{A magántốke-befektetéseket ért vádak}

A magántốke terjeszkedésének 2001 óta tartó hullámát növekvő médiafigyelem és kritika kísérte. A magántốke-befektetéseket ért támadások élharcosai a kivásárolt cégek dolgozóit képviselő szakszervezetek voltak, amelyek a politikusok körében is támogatókra leltek. Az ágazat elleni támadás a médiában ismertté vált egyedi esetek, így fóként a tốzsdén jegyzett nagyvállalatok kivásárlása kapcsán indult meg, $\mathrm{s}$ vezetett a pénzügyi szolgáltatások reformjának keretében a magántôke-befektetók szigorúbb szabályozásának követeléséhez. A magántốke-ágazat múködését érintő vitát a pénzügyi és gazdasági válság is felerốsítette, tekintve, hogy recesszióban a nagy hitelteherrel rendelkező cégekre különösen nagy nyomás nehezedik, miközben a magántőke-ágazat múködése maga is megnehezül.

A magántőkeipar ellenző́i a magántốkealap-kezelőket sok esetben a cégek lemeztelenitésével vádolták (asset stripping). A vádak között tehát elsố helyen a vállalatok „,megkopasztása” állt, azaz amikor a befektetốk a vállalat vagyonát felhasználva a kivásárlás finanszírozására jelentôs tókét vontak ki a cégekból, amelyeken azután rövid idốn belül túladtak. Ez - amennyiben eleve azzal a céllal vesznek meg egy céget, hogy a vagyona eladása után hitelezóit, dolgozóit és nyugdíjjogosultjait kifizetetlenül hagyják - büntetôjogi kategória.

Emellett a magántókealap-kezelóket az a kritika is érte, hogy portfoliocégeiket olyan restrukturálásra sarkallják, amely negatív hatást gyakorol a foglalkoztatásra és az alkalmazottak díjazására. A magántőke-befektető́k iránti rokonszenvet nyilvánvalóan nem növelte, ha a kivásárlást követô beavatkozás nyomán jelentős átalakitásra került sor a portfoliocégeknél, ami esetenként jelentôs elbocsátásokhoz és a dolgozók fizetésének csökkenéséhez vezetett.

A magántốke megjelenésétôl ennek ellenzői a cégek jövôje szempontjából fontos, hosszú távú befektetések elmaradását is féltették. Továbbá azzal érveltek, hogy a cégek hitelekkel való megterhelése és offshore tulajdonba kerülése csökkenti az adókötelezettséget, s ez vezet azután a befektetések kiugró pénzügyi teljesítményéhez.
A magántóke ellenzői szerint a magántốke nem a portfoliocégek múködése révén ér el rendkívül magas hozamokat, hanem a cég többi érdekeltjének kárára történő érték eltulajdonításával (Financial Services Authority, 2006; ITUC, 2007; PSE Group in European Parliament, 2007). E vádak végül a magántốkeipar vizsgálatának elszaporodását váltották ki, így többek között a Treasury Select Committee (2007) vizsgálatához vezettek az Egyesült Királyságban és az Amerikai Kongresszusban. A nagyfokú érdeklődés az iparágat meglepetésként érte (Walker, 2007). A válaszreakció egy sor kutatás, jelentés és az iparági legjobb gyakorlatra tett javaslat készítésére szóló megbízás lett.

\section{A magántókeipar saját elemzései}

A magántôkeipart, illetve az e piacon múködő befektetôket ért vádakkal szemben az ágazat egy sor olyan felmérési eredményre hivatkozott, amely a befektetốk érdekvédelmét ellátó intézmények megrendelésére készült. A magántốke-befektetések általános hatását elemzố munkák közül azok a - kockázati-és magántóke egyesületek megrendelésére viszonylag rendszeresen készülő - felmérések a legismertebbek, amelyek a magántốkével finanszírozott vállalkozások teljesítményét hasonlítják össze a gazdaság egészének, vagy a vállalatok valamely csoportjának eredményeivel, így például a tôzsdei cégek vagy a legnagyobb méretú vállalkozások adataival.

A fenti elemzések egyik sokat hivatkozott példája az Európai Kockázati és Magántóke Egyesület (EVCA) megbízásából a Müncheni Múszaki Egyetem Center for Entrepreneurship and Financial Studies (CEFS) intézete által 2005-ben készített felmérés. Ez megvizsgálta, hogy Európában a magántőke-ipar hogyan járult hozzá az általa létrehozott munkahelyek révén az európai munkahelyteremtéshez (EVCA, 2005). A felmérés készítői a válaszadásra felkért alapoktól az 1997 és 2004 között befektetésben részesített portfoliocégeikról kértek információt, melynek nyomán közel 200 magántókét kapó cégról állt rendelkezésre adat. A felmérés eredményei azt mutatták, hogy az európai magántôke által finanszírozott cégek 2000 és 2004 között egymillió új állást hoztak létre. A magántő́ke által finanszírozott cégekben foglalkoztatottak száma átlagosan évi 5,4\%kal nőtt a vizsgált négy év során. A felmérés készítőinek számítása szerint ez nyolcszor akkora ütem volt, mint az összes foglalkoztatott számának 0,7\%-os éves növekedési üteme 2000 és 2004 között az EU 25 tagállamában. A felmérés adatai szerint a magántốke által finanszírozott vállalkozások 2004-ben közel hatmillió embert foglalkoztattak Európában - ami a 200 millió 
fốs gazdaságilag aktív európai népesség 3\%-ának felelt meg. A felmért cégek 33\%-a évente átlagosan több mint 5\%-kal növelte létszámát 1997 és 2004 között. A magántóke által finanszírozott portfoliocégeknél a foglalkoztatottság növekedési üteme a felmérés szerint jelentősen meghaladta az összes munkahely növekedésének rátáját Európában.

Hasonlóan pozitív kép rajzolódott ki az amerikai Nemzeti Kockázati Tóke Egyesület (NVCA) által a Global Insight cégtől megrendelt felmérésból, mely az Egyesült Államokban a kockázati tốke gazdasági hatását 23 és fél ezer, 1970 és 2005 között magántốkebefektetésben részesült cég vizsgálatán keresztuil elemezte (Global Insight, 2007). E felmérés eredményei azt mutatták, hogy a kockázati tókével finanszírozott cégek az amerikai gazdaság minden szektorában jelen voltak, s összesen tízmillió embernek adtak munkát. A kockázati tôkét kapó cégek 2005-ben a magánszektorbeli munkahelyek 9\%-át képviselték. 2003 és 2005 között a foglalkoztatottak száma a kockázati tókével finanszírozott cégeknél 4,1\%-kal nôtt, míg ezalatt országos szinten 1,3\%-os volt a foglalkoztatottak számának növekedése (Global Insight, 2007).

A fenti számítások azonban meglehetôsen sok becslést tartalmaztak, sốt az általuk alkalmazott összehasonlítások módszertanilag is sok tekintetben megkérdójelezhetók, s nyilvánvalóan elfogultak voltak a magántóke-iparág iránt. A magántóke-iparág pozitív hatásokat hangsúlyozó felméréseire válaszul például egy, az UNITE szakszervezet T\&G tagszervezete által megrendelt tanulmányban Hall (2007) több olyan elemzés eredményének tudományos voltát is megkérdőjelezte, amely a magántốke-befektetések pozitív gazdasági hatásairól számolt be, hangsúlyozva, hogy az elemzések hibás módszertan alapján jutottak a közölt következtetésekhez. A szakszervezeti megrendelésre 2007-ben készült elemzés elismerte, hogy az elmúlt néhány évben a magántókével finanszírozott cégek foglalkoztatottainak száma valószínúleg nôtt. De ennek szerinte az volt az oka, hogy a magántóke-tulajdonban lévő cégek száma és mérete nôtt meg az elmúlt években erôteljesen, azaz a fenti adat önmagában az egyes cégek szintjén nem feltétlenül tükröz bármiféle növekedést. Mindez csupán a magántôkealapok növekedéséról árulkodik, s nem mond semmit a konkrét cégek foglalkoztatottsági viszonyairól, arról, hogy az magasabb vagy alacsonyabb-e, mint lett volna a tulajdonosok megváltozása nélkül.

Hall (2007) szerint a magántôke-ágazat érdekképviseleti szervezeteinek megrendelésére készült felmérések módszertani fogyatékossága fóként a magánszektorban múködő cégekről elérhetố információk hiányos voltából fakad. Ennek következtében a szektor hatását vizsgáló kutatások nem teljes körúek, hanem önkényesen kiválasztott cégek, ráadásul nem tényleges, hanem becsült adatain alapulnak. Mivel az érintett cégektól önkéntes módon kérik be az információkat, a jobban teljesítô cégek inkább bekerülnek a mintába, míg a gyengébben teljesítók kimaradnak, ami úgy torzítja az eredményeket, hogy a felmérés készítói ellenórizni sem tudják a kapott adatokat. Az adatok összegyújtése azoktól, akik választhattak, hogy válaszolnak-e vagy sem, illetve a csak túlélố kivásárolt cégektól (azaz, amelyek nem mentek csődbe), nem vezethetett reprezentatív eredményhez. A felmérések ugyanis nem számoltak a túlélési ráta hatásával, azaz csak a sikeres cégeket nézték, s nem vették figyelembe az idóközben tönkrement cégek sokkal népesebb hadát.

Noha a magántóke-befektetések hatásáról az elmúlt húsz évre vonatkozóan kiterjedt tudományos szakirodalom áll rendelkezésre, a nyilvánosság előtt zajló vita nagy része a magántő́ke-ágazat megrendelésére készített, szükségképp nem objektív tanulmányok adatain, más oldalról a nyilvánosságra került kirívó eseteken alapult. Holott a tudományosan ellenórzött adatokat és korrekt módszertant alkalmazó tanulmányok száma is eléri a százat, s ezek alapján kiegyensúlyozott álláspont szû́rhető le a magántóke-befektetések hatásáról (Wright és társai, 2009). A tudományos szakirodalom már egy sor olyan témát megvizsgált, ami fényt derít a magántốke hatását érintô alapvetô kérdésekre. A kiemelt kérdések közé tartozik többek között a magántốkealapok és ezek befektetói által elért hozamok nagysága, a magántốke portfoliocégeinek hasonló adottságú vállalkozásokhoz viszonyított jövedelmezősége és termelékenysége, a portfoliocégeknél a befektetések foglalkoztatásra és a bérekre gyakorolt hatása, illetve mindezen hatások maradandósága a magántő́kebefektetốk kiszállása után.

\section{A befektetések hozama}

A tudományos kutatások összességében nem igazolják, hogy magántóke-befektetôk a portfoliocégek megkopasztásával óriási hozamokat zsebelnének be (Gottschlag, 2007). A magántóke-befektetók által elért hozamokról a legtöbb elemzés az amerikai piacra vonatkozóan készült, s arra igyekezett választ adni, hogy a magántôkeügyletek a nyilvános értékpapírokba történt befektetésekhez képest jobb vagy rosszabb hozamokat értek-e el. Egy 5500 kivásárlás adatait feldolgozó kutatás arra a következtetésre jutott, hogy történelmi távlatban nézve a magántốkealapok 3 százalékkal magasabb bruttó éves hozamokat értek el a nyilvános részvénypi- 
aci indexekhez képest. Ugyanakkor a magántőkealapok kezelőinek díjazása miatt a magántő́kealapok befektetôi 3 százalékos hozamelmaradásban voltak a nyilvános részvénypiaci befektetők által elért indexekhez képest. Azaz, a kezelési díjak 6 százalékos különbséget eredményeztek a bruttó és a nettó hozamok között (Gottschlag, 2007). A kezelóknek járó díjat és sikerdíjat egyaránt fedezô 6 százalékos eltérés más alapkezelốk díjaihoz viszonyítva magasnak tûnik, ám azt tükrözi, hogy a magántốkealapok sokkal több erőfeszítést és sokkal nagyobb jártasságot követelnek meg kezelóiktôl, mint más alapok. Gyakorlatilag ez azt jelenti, hogy az intézményi befektetôknek a magántôkealapokba való befektetés 3 százalékkal alacsonyabb teljesítményt eredményezett a nyilvános piacokon elérhetó hozamoknál. Ugyanakkor a legjobban és a legrosszabbul dolgozó magántôkealapok között óriási eltérés mutatkozik, mivel a legjobbak több mint a tízszeresét érték el a tôzsdei hozamoknak, miközben a legrosszabbak a nekik odaígért tóke nagy részét elbukták.

A befektetốk szempontjából a magántốkealapok kiválasztásának rendkívül nagy a jelentősége, hiszen a befektetốk a tôzsdei indexektốl eltéróen nem tudnak „magántôkeindexet” venni. Ugyanakkor a befektetốk számára meglehetôsen nehéz a legjobbak kiválasztása, mivel az alapok pontos összehasonlítását az általuk közölt mutatók és benchmarkok nehezen teszik lehetôvé.

Az alapkezelők jellemzőinek fontosságát húzza alá, hogy a felmérések tanúsága szerint a legjobban teljesító alapok tartósan jobb teljesitményt értek el, azaz a már megállapodottabb, nagyobb tapasztalatokkal rendelkezó alapok általában magasabb hozamokat produkáltak. Az alapoknál az egy fơre jutó kevesebb projekt és kisebb portfolioméret alaposabb átvizsgálást és jobb hozamokat eredményezett, miközben az egy befektetési szakemberre jutó magasabb kezelt összeg a nagyobb méretú kivásárlási alapoknál eredményezte a legmagasabb hozamot a többi alaphoz képest (Kaplan - Schoar, 2005).

A hozamok alakulására kezelőik jártassága mellett az alapok létrehozásának idốpontja is befolyással van. Például a nyolcvanas években gyújtött magántôkealapok magasabb hozamúak voltak, mint a kilencvenes években létrehozottak. A fellendülés idején gyuujtött alapok kezelói kisebb valószínúséggel tudtak újabb alapokat létrehozni, ami végsố soron azt jelezte, hogy kevésbé jó teljesítményt értek el. Ám nemcsak az alapok létrehozásának idôpontja és kezelőinek jártassága hat ki a magántókealapok hozamaira, de az alapok befektetóinek összetétele, illetve kiléte is. A kutatások szerint például szélesebb sávban alakulnak a hozamok az alapítványok és a nyugdíjpénztárak által finanszí- rozott alapok esetében, valamint a bankok és egyéb befektetốknél. A magántôkke-befektetésekben kevésbé jártas, és a teljesítményre kevésbé érzékeny befektetốk sokszor a rosszabbul teljesító alapok számára is lehetôvé teszik új alapok gyưjitését. Emellett a magántókebefektetés hozamát felülíró egyéb szempontok, azaz például a stratégiailag fontos befektetókkel létrehozott kapcsolt ügyletek is torzíthatják az adatokat (Lerner és társai, 2007).

A kivásárlási alapok belsố megtérülési rátái konzisztensen magasabbak a kockázatitóke-befektetésekéhez képest, ami az életciklusuk késôbbi fázisában lévô cégek nagyobb hozamát jelzi. A kutatók azt is kimutatták, hogy a korai fázisú finanszírozás hozamai általában magasabbak voltak az Egyesült Államokban, mint Európában (Wright és társai, 2009). Például az 1991 és 2007 közötti időszakot alapul véve, a kockázatitôkebefektetések átlagos hozama - ötéves gördülő belsố megtérülési ráták alapján számolva - Európában 6,9\% volt, míg az Egyesült Államokban 18,9\% (Clarysse és társai, 2009).

Az alapok által elért hozamokat a befektetóknek az egyes ügyletekból történố kilépési módja is befolyásolja. A legjobb eredményeket azok a portfoliocégek produkálták, amelyekkel a befektetốk első ízben jelentek meg a tôzsdén (IPO), míg második helyen a szakmai befektetốknek történố cégeladások szerepeltek. Emellett a nagyobb összegú tớkebefektetés és a portfolióban tartás idején végrehajtott több felvásárlás is jobb hozamokat eredményezett a befektetôknél (Nikoskelainen - Wright, 2007).

\section{A portfoliocégek teljesítménye}

A magántốke-befektetók portfoliojába került cégekre vonatkozó felmérések szerint a jövedelmezőség és a cash-flow mutatatók terén a nyolcvanas években végrehajtott amerikai kivásárlások jelentốs átlagos javulást mutattak a kivásárlást megelőzố egy év és a kivásárlást követô két vagy három év során (Bull, 1989; Kaplan, 1989; Malone, 1989; Singh, 1990; Opler, 1992; Muscarella - Vetsuypens, 1990). A nyolcvanas évekre az Egyesült Királyságban mért adatok is azt mutatták, hogy a kivásárlások túlnyomó többsége egyértelmúen javulást ért el a portfoliocégek jövedelmezőségében (Wright és társai, 1992). A vezetói kivásárláson átesô angol cégeknél az 1980-as évek közepén jelentôsen gyorsabban nőttek a vagyonarányos hozamok a kivásárlás utáni kettô-öt év során, mint más hasonló olyan cégeknél, ahol nem került sor vezetôi kivásárlásra (Wright és társai, 1996/b). Az Egyesült Királyságban a kivásárláson át nem esett cégekhez viszonyítva a tel- 
jes céget érintő vezetői kivásárlások termelékenységre gyakorolt hatásánál a kutatók jelentós javulást tapasztaltak a hatékonyságban a kivásárlást követô négy évig (Amess, 2002, 2003). Hollandiában a közepes méretú kivásárlások cash-flow, árbevétel- és hozamelemzése azt jelezte, hogy az adott ágazatbeli más cégek átlagos pénzügyi mutatóihoz képest e cégek számottevően jobb eredményt mutattak (Bruining, 1992). A vezetôi kivásárlások az azonos ágazatokban múködő hasonló cégekkel összehasonlítva Franciaországban jobb teljesítményt értek el a kivásárlás előtt és után egyaránt (Desbrieres - Schatt, 2002).

A kutatók úgy vélték, hogy a vállalati szintú adatokhoz képest a telephelyszintú adatok sokkal alkalmasabbak a kivásárlások közgazdasági, mint pénzügyi eredményeinek lemérésére. A telephelyek a cégek olyan fizikai egységei, amelyek szintjén a fizikai output és input, illetve az eróforrások termelésbeni felhasználása számszerüsíthetố. Az amerikai telephelyszintú adatok azt jelzik, hogy a vezetốk által kivásárolt telephelyeknél a tulajdonosváltás elôtt magasabb volt a teljes ipari termelékenység (TFP), mint ugyanazon iparág hasonló létesítményeinél. A kivásárlás után a kutatók jelentôs javulást tapasztaltak a teljes ipari termelékenységben úgy, hogy a gazdasági teljesítmény javulása nem a $\mathrm{K}+\mathrm{F}$ területén, a béreknél, a tő́keberuházásoknál, avagy a dolgozók elbocsátásánál jelentkezô megtakarítások révén következett be (Lichtenberg - Siegel, 1990). Lichtenberg és Siegel (1990) 131 olyan kivásárolt feldolgozó-ipari cégnél elemezte a termelékenység alakulását, ahol a tranzakcióra 1981 és 1986 között került sor. E felmérés a kivásárlást követően a vizsgált üzemeknél a kontrollcsoporthoz viszonyítva sokkal gyorsabb termelékenység-növekedést talált, noha a kivásárolt üzemek a kivásárlást megelőzően is hatékonyabbak voltak.

Harris és társai (2005) az Egyesült Királyságban 1994 és 1998 között végrehajtott 979 kivásárlás adatait elemezve arra a következtetésre jutottak, hogy a tulajdon átruházása elốtt a vezetốk által kivásárolt létesítmények eleve kevésbé voltak produktívak, mint a többi hasonló feldolgozó-ipari üzem. Ennek ellenére a vezetốk által kivásárolt üzemeknél a termelékenységben jelentốs növekedést mértek a kivásárlás után. A gazdasági teljesítmény javulása elsôsorban a közbenső termékek és anyagok gyártásának kiszervezése útján történő racionalizálásnak volt köszönhető.

A fenti elemzések nem vizsgálták a termelékenység növekedésének forrásait, azaz azt, hogy az mennyiben volt köszönhetô a tovább múködő telephelyeknél mért termelékenységjavulásnak, s mennyiben a kevésbé és a jól teljesítő létesítmények közötti tő́keallokációnak, azaz a telephelybezárásoknak és -felvásárlásoknak. Ezért is érdemel figyelmet Davis és társainak (2009) közelmúltban publikált kutatása, amely az amerikai magántốke-befektetési tranzakciók termelékenységi, kereseti és foglalkoztatási hatásait egész vállalatokra, valamint ezek telephelyeire vonatkozó adatok felhasználásával mutatta be, $\mathrm{s}$ mutatott rá a cégen belüli restrukturálás és reallokáció jelentőségére, a piacra való be- és kilépés, a felvásárlás és leépítés által elôidézett változásokra. Az elemzés szerint a magántőke-befektetốk portfoliocégeinél más cégekhez képest intenzívebb volt a munkahelyek teremtése és megszüntetése, a telephelyek létrehozása és megszüntetése, a telephelyek felvásárlása és eladása. Mindezen folyamatok nettó hatásaként a reallokáció intenzívebbé válása jelentôs, $2 \%$ körüli termelékenységnövekedési elônyt hozott a tranzakciókat követô első két év során. Ezen előny kétharmada a portfoliocégek tovább múködő telephelyeinél bekövetkezett termelékenységnövekedésnek volt köszönhetô, beleértve e létesítmények közötti jobb allokáció hatását. Egyharmada pedig az a hatás volt, amit a portfoliocégek kontrollcsoporthoz viszonyítva nagyobb valószínúséggel bezárt rosszul teljesítő részlegei eredményeztek (Davis és társai, 2009).

Strömberg (2009) a témát vizsgáló, sokféle kutatás tapasztalatait összegezve végül is arra az általános következtetésre jutott, hogy a magántóke-befektetés javítja a vállalati teljesítményt. Úgy vélte, hogy az adatok alapján a magántốke-befektetést követően túlnyomórészt pozitív a portfoliocégek üzemi teljesítménye. A hitel igénybevételével végrehajtott kivásárlások hatására javul a termelékenység és a tôkehatékonyság, sốt az európai ügyleteknél nagyobb a teljesítménynövekedés, mint az amerikai kivásárlásoknál. A magántőke-befektetéseken belül a klasszikus kockázati tốkét kapó cégek a kontrollcsoport cégeinél gyorsabban növekedtek, és termékeiket gyorsabban vitték ki a piacra. A cégek pénzügyi teljesítményére gyakorolt pozitív hatás nem a hosszú távú befektetés és növekedés kárára történt, azaz a portfoliocégek innovációs befektetései, $\mathrm{K}+\mathrm{F}$ ráfordításai és termelékenysége egyaránt noottt. Sőt, a magántốke-befektetések előnyös hatása még azután is folytatódott, amikor a befektetók már kiszálltak a cégekből. Az első tôzsdei megjelenések esetében különösen érvényesült a magántőke-hátterú cégek jobb teljesítménye a más tulajdonosi hátterú cégekhez képest.

\section{A magántốke-befektetések élettartama}

Miben különbözik a magántốkemodell más tulajdonlási formáktól - fớként a nyilvános cégek tulajdonlásától -, s ez az eltérés milyen hatást fejt ki a portfolio cégekre? 
Az egyik alapvető kérdés a befektetések időtartama. A magántốkealapok befektetési idóhorizontja a tôzsdén jegyzett cégek intézményi befektetôinél hosszabb. Ez elvileg a cégek hosszú távú érdekeit inkább figyelembe vevố döntések meghozatalát teszi lehetôvé. Ugyancsak lényegi különbség, hogy a magántốkealapok kezelói nem pusztán tôkét fektetnek be a cégekbe, hanem - eltérően más intézményi befektetốktől - maguk is aktívan beleszólnak a portfoliocégek stratégiájának kialakításába és segítik a menedzsment munkáját. A portfólió cégek és így az alapok sikere jelentôs mértékben múlik az alapkezelóknek a portfoliocégek menedzselésében való aktív részvételén. A magántốkealapok tulajdonában lévő cégek vállalatkormányzási gyakorlata gyakran erôteljesebb más cégekénél. Vezetôik tulajdonosi érdekeltsége és teljesítményalapú kompenzációs rendszere eróteljes ösztönzést jelent a sikerre, amit felerósít az alapok ellenőrzést biztosító tulajdoni hányada. Ez a szorosabb kontroll mellett a teljesítmény alapján végrehajtott gyors vezetôváltásokban is érezteti hatását. A vezetés hatékonyságához a más vállalatokhoz képest kisebb létszámú és arányosan kevesebb belső taggal rendelkezó vezetố testületek is hozzájárulnak (Strömberg, 2009).

A magántốke-befektetések portfóliócégekre gyakorolt konkrét hatását befolyásolja, hogy a magántőke-tulajdonlás mennyi ideig tart a kivásárolt cégeknél. Lerner és Gurung (2008) a 2008-as Világgazdasági Fórum felkérésére készített átfogó felmérése szerint, mely az 1970 és 2007 között végrehajtott magántóke-befektetési ügyletek részleteit vizsgálta, a hitellel kivásárolt cégek viszonylag hosszabb ideig maradnak a magántốke-befektetók portfoliojában. A befektetôk döntései tehát hosszú távon befolyásolják az érintett cégek életét. A vizsgálat adatai szerint a kivásárolt cégek 40\%-a még a kivásárlási ügyletek bejelentésétól számított tíz év múlva is e szervezeti formában maradt. Ráadásul a portfolioban tartás ideje az elmúlt években tovább nőtt. A befektetést követô öt év elteltével már a portfoliocégek 58\%-ából léptek ki a befektetők, míg a két éven belüli (azaz villám)kilépések az ügyletek $12 \%$-ára voltak jellemzók. Ezen villámakciók aránya, amelyekkel kapcsolatban a legtöbb negatív kritika érte az ágazatot, az elmúlt néhány évben csökkent (Lerner és Gurung, 2008). Egy másik felmérés (Gottschlag, 2007) ugyancsak azt erősítette meg, hogy meglehetôsen idôigényes a cégek olyan átalakítása, amely megfeleló hozamot képes biztosítani a befektetóknek. E kutatás szerint a befektetốk portfoliocégeiket átlagosan öt évvel a kivásárlást követően adták el. A 24 hónapnál rövidebb idôt a befektetốk portfoliojában töltő cégek aránya $16 \%$ volt. A fenti adatok különösen a nyilvános cégek esetében tapasztalt, havi egyszeri eladási gyakoriság fényében értékelhetốk. A felmérés készítoói szerint még az 5\% felettinél nagyobb részvényhányadot birtokló ún. blokktulajdonosok is átlagosan rövidebb ideig birtokolták részvényeiket, mint a magántôke-befektetôk (Gottschlag, 2007).

\section{A portfoliocégeknél mért foglalkoztatás}

A túlfútött gazdaságpolitikai viták középpontjában elsôsorban a magántốke-tranzakciók foglalkoztatásra gyakorolt hatása áll. Ugyanakkor a kivásárlások foglalkoztatásra gyakorolt hatására vonatkozó adatok igen vegyes képet mutatnak.

Összesen 43 különbözố tudományos felmérés elemzése alapján Nathusius és Achleitner (2009) úgy vélte, hogy a kontrollcégekhez képest mért foglalkoztatási adatok nagy valószínúséggel az érintett piacok fejlettségi fokától függóen mutatnak eltéró eredményeket. Így az USA és az Egyesült Királyság esetében a kivásárlások hatásaként csökkent a foglalkoztatottak száma, míg a francia, spanyol és belga piacon emelkedett. A szerzók ebból arra következtettek, hogy a kevésbé fejlett piacokon a magántóke-befektetốk a cégek olyan külső forrásokból finanszírozott növekedését tudják elôidézni, amely egyébként korlátokba ütközne. Megállapították továbbá, hogy a magántóke által finanszírozott vállalkozások hasonló társaikhoz képest több zöldmezốs állást hoznak létre, $\mathrm{s}$ aktívabbak a felvásárlások és leépítések terén.

A magántôke-befektetések foglalkoztatási hatását vizsgáló kutatások felhívják a figyelmet arra, hogy a magántőke-befektetốk nem véletlenszerúen választják ki a befektetési célpontokat, azaz kevéssé valószínú, hogy a kivásárlás előtt az érintett cégek jobban teljesítenek a társaiknál, mivel így a restrukturálás kevés hozamot eredményezne. Az adatok szerint az Egyesült Királyságban az MBO/MBI kivásárlás által érintett üzemek a kivásárlást megelôzóen átlagosan alacsonyabb teljes ipari termelékenységi mutatókkal (TFP) rendelkeztek, mint a magántóke által nem érintett társaik. Így talán nem meglepó, hogy esetükben inkább fordult eló a munkaeró elbocsátása. Ugyanakkor a kivásárlás idején a munkaerố elbocsátása a cégeket egy sokkal életképesebb pályára helyezheti, így csökkentve a valószínúségét a - még magasabb foglalkoztatási veszteséggel járó - csốdbe jutásnak, s megteremtve a középtávú növekedés alapját.

Az USA-ban a nyolcvanas években elófordult kivásárlásokra vonatkozóan Kaplan (1989) kismértékü növekedést tapasztalt a cégek foglalkoztatásában. Ezzel szemben Lichtenberg és Siegel (1990) szerint a 
kivásárlások nem növelték az ipari átlagoknak megfeleló ütemben a foglalkoztatottságot. E kutatás azt is kimutatta, hogy egy hároméves periódus alatt a termelésben közvetlenül nem részt vevô dolgozók körében volt a legnagyobb visszaesés, miközben a termelésben dolgozók létszáma nem változott. Az Egyesült Királyságra vonatkozó nyolcvanas évekbeli adatok szerint a munkahelyek elvesztése leginkább a tulajdonoscsere idején fordult elő (Wright '- Coyne, 1985), s mivel a brit kivásárlások a nyolcvanas években a mostaninál sokkal inkább a bajba került cégek restrukturálására fókuszáltak, ez hosszú távon a munkahelyek számában megtakarításhoz vezetett. A kivásárlásokra vonatkozó, 1999 és 2004 között megfigyelt brit adatok már azt mutatják, hogy a tulajdonosváltás után a foglalkoztatás 0,51 százalékponttal emelkedett a vezetôi kivásárlások (MBO) esetében és 0,81 százalékponttal csökkent a külsố menedzserek bevonásával végrehajtott vezetôi bevásárlások (MBI) esetében, beleértve az intézményi befektetốk által kezdeményezett kivásárlásokat (IBO) (Amess - Wright, 2007). Cressy és társai (2007) úgy találták, hogy az Egyesült Királyságban vizsgált magántôkeügyletek körében az elsó négy évben csökken a foglalkoztatás a kontrollcsoporthoz képest, majd az ötödikben emelkedik. Ez feltehetóleg azt jelzi, hogy egy kezdeti racionalizálás a sokkal életképesebb munkahelyek létrehozásának alapját teremti meg.

Lerner és Gurung (2008) az 1980 és 2005 közötti amerikai magántőke-befektetésket vizsgálva azt állapította meg, hogy a foglalkoztatás a magántôke által kiválasztott portfoliocégek telephelyeinél a kontrollcsoporthoz képest lassabban nőtt a befektetés évében és az azt megelőzô két évben. A kivásárlás előtti két évben a kumulált eltérés $4 \%$ volt a kontrollcsoport javára. A magántốketranzakciók nyomán a foglalkoztatás a portfoliocégek telephelyeinél jobban visszaesett. Két év alatt a kumulált eltérés 7\% volt a kontrollcsoport javára. A foglalkoztatás a kontrollcsoportban a befektetést követő három évig gyorsabban nőtt. A negyedik és az ötödik évben azonban a foglalkoztatás növekedése a portfóliócégek telephelyeinél már megegyezett a kontrollcsoportéval. A befektetést követôen a magántóke által kivásárolt cégek telephelyeinél a kontrollcsoportéval nagyjából azonos volt a létrehozott állások száma. Az összes létrehozott állás - azaz új foglalkoztatást biztosító állás - a két körben hasonló volt, s a nettó eltérés a portfóliócégek telephelyeinél mért több álláshely-megszüntetés következménye volt (Lerner - Gurung, 2008).

A kutatók felhívták a figyelmet arra, hogy a kivásárlásoknál a foglalkoztatás hatásának becslését számos módszertani probléma nehezíti. Ilyenek a felvásárlások és leválasztások hatásának kezelésével, a teljes és a részmunkaidős foglalkoztatásnál bekövetkezó sok változás követésével kapcsolatos nehézségek. A nyilvános adatok általában nem tartalmaznak részleteket a kivásárlást követően felvásárolt vagy eladott tevékenységek foglalkoztatási oldaláról. Az üzemi szintú adatokból számított általános foglalkoztatási hatást mérsékelheti, ha a kivásárló cégek olyan vállalatokat vásárolnak, amelyeket késốbb az általuk alapított új telephelyekbe olvasztanak.

A Davis és társai (2008) által készített tanulmány épp a fenti kérdések kezelését igyekezett megoldani. Megállapította, hogy a teljes munkaidôs foglalkoztatásról a nagyobb arányú részmunkaidős foglalkoztatásra való áttérés is emelheti az összes foglalkoztatott létszámát, miközben nem jár hasonló hatással a teljes munkaidőre átszámított foglalkoztatásra. A gyakorlatban azonban nem állnak rendelkezésre az ezek hatását megkülönböztetô adatok. Davis és társai (2008) a magántớke és nem magántő́ke hátterú amerikai cégek és ezek telephelyeire vonatkozó adatokat összevetve azt találták, hogy az előbbieknél a foglalkoztatás a kivásárlás előtt a kontrollcsoporthoz képest sokkal lassabban nőtt, a kivásárlást követôen pedig sokkal gyorsabban esett vissza. Ugyanakkor a kivásárlást követő negyedik és ötödik évi foglalkoztatási adatokból az derült ki, hogy a kivásárlások ekkor már több új állást teremtettek.

A Világgazdasági Fórum felkérésére 2009-ben készült egyik tanulmány, amely cégeken belül, feldolgozó-ipari vállalatok telephelyei körében vizsgálta az állások számának változását, a magántôke által finanszírozott vállalkozásoknál a „teremtô rombolás” intenzívebbé válását konstatálta. Az állások létrehozására és megszüntetésére, a telephelyek létrehozására és leépítésére, felvásárlásukra és eladásukra irányuló tevékenység a magántốke által finanszírozott cégek körében sokkal intenzívebben jelentkezett, mint a kontrollcsoport cégeinél (Gurung - Lerner, 2009). Részben ez, az intenzívebbé váló kreatív rombolás, azaz az új területeken állások létrehozása, a rosszul múködő részeknél pedig munkahelyek megszüntetése magyarázza a szakszervezetek és politikusok vagyonkivonással és „féktelen” költségcsökkentéssel kapcsolatos aggodalmát. Ugyanakkor ezek az intézkedések azzal, hogy a cégek sokkal hatékonyabb tevékenységekre csoportosítják át eróforrásaikat, segítik a pénzügyi feszültségek idôszakában a termelékenység javítását. A kutatók megállapítása szerint a változások indukálta elônyök és a változásokkal szükségszerúen együtt járó „,súrlódási költségek” jelentős terheket rónak a cégekre és befektetókre egyaránt. 
A végsố mérleg lényegében attól függ, hogy a változások hatása mennyire lesz tartós. A kutatók mindenesetre a tartós termelékenységi és vezetési színvonalból fakadó elóny bizonyítékaként értelmezték, hogy a tôzsdén szereplő magántőke-hátterú cégek teljesítménye öt éven át meghaladta a többi hasonló cég mutatóit (Gurung - Lerner, 2009).

\section{A portfoliocégeknél mért bérek}

Egyes amerikai tanulmányok szerint a nyolcvanas években a magántốke által finanszírozott cégekben csökkent a közvetlenül nem a termelésben foglalkoztatottak fizetése a magántôke által nem érintett cégekhez képest (Lichtenberg - Siegel, 1990). Amess és Wright (2007) azt találta, hogy az MBO-k és az MBI-k egyaránt alacsonyabb bérnövekedést mutattak 1999 és 2004 között: a bérnövekedés a kontrollcsoporthoz képest az MBO-k esetében 0,31 százalékponttal, az MBI-knél 0,97 százalékponttal volt alacsonyabb a bérnövekedés. Ezt a tényt azonban nagyon óvatosan kell kezelni, mert a kivásárlást megelőző fizetési szintek sem lettek volna fenntarthatók, ha a cégek rossz teljesítményt produkáltak volna. Mivel nem állnak rendelkezésre adatok arról, hogy a kivásárlásoknál más tulajdonoscserékhez képest magasabb vagy alacsonyabb bértrend érvényesült, e téren nem vonható le megalapozott következtetés. Ugyancsak problematikus a heti/havi bérek és a dolgozók résztulajdonosi részvételét eredményezô rendszerek bevezetésébő́l eredô hatások figyelembevétele.

$\mathrm{Az}$ amerikai magántóke-befektetốk portfoliocégeinek leépítés által nem érintett telephelyeinél a nagyobb vállalatok egy dolgozóra vetítve a kontrollcsoport cégeihez képest 1,1\%-kal magasabb bért fizettek a kivásárlások idején. Két évvel késóbbi idôpontban a kutatók a bérek között már nem találtak eltérést. A bérekben átmenetileg mutatkozó többlet egyidejúleg tükrözte a telephelyeknél végbement változásokat és a telephelyek közötti allokáció hatását. A kutatások eredményei szerint a magántóke-befektető́k portfolio cégei és a kontrollcsoport cégei magasabb bérek formájában egyaránt osztoztak a dolgozókkal a magasabb termelékenység hasznán, bár a termelékenység növekedése és a bérnövekedés közötti kapcsolat valamivel erôsebb volt a magántốke-befektetók portfoliocégei esetében (Davis és társai, 2009). A Centre for Management Buyout Research 2002 és 2006 közötti 190 európai magántókebefektetési ügylet adatainak felmérésekor azt állapította meg, hogy a foglalkoztatottak érdekeit ugyanolyan vagy nagyobb súllyal vették figyelembe a magántókehátterú cégeknél, mint a korábbi tulajdonosok idején. Sốt, a magántốke-befektetés nagyobb valószínúséggel jelentette a vállalati nyugdíjrendszerben való részvételt, a magasabb keresetet, a korábbinál több konzultációs lehetôséget, valamint a szakszervezetek képviseletét. A kutatás szerint a pénzügyi ösztönzôk és a dolgozóknak a cég életébe történó korábbinál nagyobb bevonása révén nốtt a dolgozók cég iránti elkötelezettsége (EVCA-CMBOR, 2008).

Számos tudományos felmérés elemzése alapján Nathusius és Achleitner (2009) összességében úgy vélte, hogy a magántốke-finanszírozás a bérekre semlegesen hatott. A magántóke által finanszírozott vállalkozások esetében a kontrollcsoporthoz képest jellemzóbb volt a teljesítményalapú fizetés és magasabb volt a munkavállalói résztulajdonlás elterjedtsége. Mindezek alapján összességében a fenti szerzók szerint túlzott leegyszerúsítés lenne a magántốkéseket akár „angyaloknak”, akár „ördögöknek” beállítani, mivel mindkét állítás mellett és ellen is hozhatók fel érvek. Ráadásul a magántóke-befektetések különbözó fajtái - így például a vezetôi ki- és bevásárlások, a családi cégek kivásárlása, a nagyméretú konglomerátumok egyes divízióinak átvétele, illetve a tôzsdei cégek kivásárlása - mind a foglalkoztatás, mind pedig a bérek terén eltéró hatást gyakorol a kivásárolt cégekre, ám e különbségek tudományos igényú bemutatása még nem történt meg (Nathusius - Achleitner, 2009).

\section{Konklúzió}

A legtöbb magántóke-befektetés esetében a felvásárolt cégek a kivásárlást megelőzóen potenciáljuk alatt teljesítettek. Ahhoz, hogy egy 3-7 éves idóhorizonton belül a magántóke-befektetốk növelhessék cégük értékét, a cégek egyes részeinek elôször át kell esniük a szükséges restrukturáláson. Csak ezután nyílik meg a cégek növekedési potenciálja. Az átstrukturálás sok érdekelt számára fájdalmas, szinte sohasem kívánatos, ám néha elkerülhetetlen. A kivásárlás bizonyos mértékig a sebész munkájához hasonlít, mivel a betegnek a vágás fájdalmat okoz, de a kórházat jobb állapotban hagyja el, mint mútét nélkül. Gottschlag (2007) 5500 kivásárlás elemzése alapján egyaránt részletesen megvizsgálta a magántő́ke-befektetốk által elooidézett restrukturálási célú és növekedési célú változásokat. Úgy találta, hogy sok kivásárlás teremt értéket új növekedési stratégia, a befektetést követô felvásárlás, új kutatás-fejlesztési és marketingkezdeményezés, nemzetközi terjeszkedés útján és még sok más módon. Adatai azt igazolták, hogy bár valóban előfordult szimpla restrukturálási kivásárlás, ám az ilyen ügyletek aránya viszonylag kicsi, csupán az összes ügylet kevesebb mint 9 százalékánál fordult elő. Az esetek 45 százalékában a kivásárlás 
növekedési orientációjú volt, ám a legtöbb ügyletnél (46\%) mindkét elem jelen volt, azaz a restrukturálás és növekedés kombinálódott.

A magántốke-befektetốk foglalkoztatásra gyakorolt hatásáról folyó vita kapcsán a tudományos kutatási eredmények összességében eltéró konklúzióra jutottak, holott abban egyetértés van, hogy a portfoliocégek hatékonyabb múködésük révén gazdasági értéket teremtenek (Strömberg, 2009). Az amerikai és brit, hitelból történố kivásárlásokra vonatkozó tudományos kutatások egyetértenek abban, hogy a foglalkoztatás és a bérek egyaránt nőnek a portfoliocégeknél, ám más hasonló cégekhez mérve csak kissé lassabb ütemben. E felmérések megmutatták, hogy a magántôke-finanszírozásban részesülő cégek a kivásárlás előtt számottevôen alacsonyabb termelékenységi és alkalmazotti növekedést értek el, mint ugyanazon ágazatok más cégei. Ez lényegében azt jelenti, hogy a kivásárlók rendszerint a rossz teljesítményú cégekbe fektették be tókéjüket, azokba tehát, amelyek ,javításra szorultak", vagyis ahol a tranzakció előtti foglalkoztatási szintek nem lettek volna fenntarthatók. Vagyis a tudományos eredmények nem támasztják alá az állások megszüntetésére vonatkozó aggodalmakat. Ugyanakkor az ezzel szögesen ellentétes álláspontot sem igazolják, nevezetesen, hogy a kivásárlások különösen erős foglalkoztatás-bővüléssel járnának. A gyakorlati tapasztalat inkább azt a nézetet erősíti meg, hogy a magántóke portfoliocégei hatékonyabb múködésük révén gazdasági értéket teremtenek (Strömberg, 2009).

A foglalkoztatás pénzügyi mutatói terén a tudományos igényú kutatások kivétel nélkül mindenhol viszonylag magasabb munkatermelékenységet mutattak ki a magántôke által finanszírozott cégeknél. A bérek esetében a kutatók a kontrollcégekhez hasonló tendenciát állapítottak meg, azaz a magántóke-finanszírozás a bérekre semleges hatású volt. A felmérések azt is megállapították, hogy a magántóke által finanszírozott vállalkozások esetében a kontrollcsoporthoz képest jellemzóbb volt a teljesítményalapú kompenzáció, valamint magasabb volt a dolgozói munkavállalói résztulajdonlás aránya (Nathusius - Achleitner, 2009).

A kivásárlások többségénél a felvásárolt cégek jobb állapotban voltak a kivásárlás után, mint előtte. Vagyis jövedelmezóbben múködtek, s növekedési mutatóik is jobbak voltak. Sớt, a kivásárlások folyamán a cégek az érintett ágazat hasonló cégeihez viszonyítva is jobb teljesítményt értek el. Végül a magántôke-befektetốk kiszállása után a cégek továbbra is jobban teljesítettek, mint a kontrollcsoport cégei. Ezért a kutatók arra a következtetésre jutottak, hogy a kivásárlások olyan eszközt képviselnek a felvásárolt cégek számára, ami- vel - a versenyképesebb cégek létrehozása érdekében - előmozdítják és lehetóvé teszik a szükséges átstrukturálási és növekedési lépéseket. Ha nem ez lenne a helyzet, a magántóke-befektetốk sosem tudnák olyan értékelés mellett eladni cégeiket, ami lehetővé teszi számukra a megcélzott hozamok elérését. Természetesen a fenti összefüggés alól vannak kivételek. Előfordul, hogy a cégek csődbe jutnak, rossz döntések születnek, visszaélés történik a kivásárlási struktúrával, s az is megtörténik, hogy a magántôke-befektető lerombolja, nem pedig építi a céget. Azonban ezek a kivételek (Gottschlag, 2007).

A fenti kutatások nem igazolják, hogy magántókebefektetók a portfoliocégek „megkopasztásával” zsebelnének be óriási hozamokat, továbbá, hogy negatív hatást gyakorolnának az érintett szektorok növekedésére vagy versenyképességére, illetve hogy instabillá tennék magát a pénzügyi és gazdasági rendszert (Gottschlag, 2007). Ellenkezóleg, az adatok azt támasztják alá, hogy a magántóke-befektetést követően túlnyomórészt pozitív a portfoliocégek üzemi teljesítménye. A kivásárlások hatására javul a termelékenység és a tôkehatékonyság, s ez nem a hosszú távú befektetés és növekedés kárára történik. A magántốke-befektetések előnyös hatása általában még azután is folytatódik, amikor a befektetók már kiszálltak a cégekból. Az első tôzsdei megjelenések (IPO) esetében pedig különösen érvényesül a magántő́ke-hátterú cégek jobb teljesítménye a más tulajdonosi hátterú cégekhez képest. A magántốke által finanszírozott vállalkozások hasonló adottságú társaikhoz képest több új állást hoznak létre, igaz, több korábbiról is le kell mondaniuk.

A magántốke-befektetések hatását az érintett piacok fejlettsége is befolyásolja. A kevésbé fejlett piacokon a magántőke-befektetők a cégek olyan külsô forrásból finanszírozott növekedését tudják előidézni, ami egyébként korlátokba ütközne. Makroökonómiai szinten a hitel igénybevételével megvalósított magántőkebefektetések a tóke jobb allokációjához vezetnek, s ezzel emelik a gazdaságok hatékonyságát. A gazdaságok átstrukturálását felgyorsító eszközként elősegítik, hogy a részvénytốke kiszabaduljon az alacsony hozzáadott értéket termeló ágazatokból, s befektethetố legyen olyan magasabb hozzáadott értékú, feljövő ágazatokba, amelyek egyébként nem lennének finanszírozhatók (Strömberg, 2009).

A befektetéseknél a saját tókerész hitellel való kiegészítését, azaz a hitel részarányát a kivásárlási struktúrában rendszerint nagy figyelem kíséri. Ugyanakkor kevesebb figyelmet kap az az ennél is fontosabb szempont, hogy a kivásárlás mennyire növeli meg a felvásárolt cég jövedelemtermeló képességét, tehát a kivá- 
sárolt cég lehetőségét a hitel visszafizetésére. Holott a hitel részarányához képest a kamatfizetés cash-flowval történő lefedése a hitelek visszafizetési képességének sokkal kifejezóbb jelzőszáma. A magántőke-ügyletek ugyanis képesek fenntartani a magas tókehitelezési arányt is, ha megvan ehhez a kellóen magas és stabil kamatfedezetük.

A hitel magas aránya azonban a magántőkekonstrukcióban potenciális kockázatnak teszi ki a portfoliocégek életképességét. A nagyobb amerikai és angol kivásárlások kutatási eredményei erôsen alátámasztják az összefüggést a magasabb hitelarány és a bukás, vagy restrukturálásra szorulás megnövekedett valószínúsége között (Bruner - Eades, 1992; Kaplan - Stein, 1993; Wright és társai 1996/a). A hitelek magas aránya azonban nemcsak a magántóke által finanszírozott cégeket érinti drámai módon. A kivásárlások bukási arányára vonatkozó legfrissebb elemzésból az derül ki, hogy a magántốke által finanszírozott cégek tönkremenési aránya nem magasabb, mint a más módon finanszírozottaké (Economist, 2009).

\section{Lábjegyzet}

\footnotetext{
${ }^{1}$ A magántóke-befektetés vállalatfinanszírozással professzionálisan foglalkozó alapok olyan befektetése, amely tulajdonosi szerep ellenében nyújt tôzsdén nem jegyzett cégek számára hosszú távra külső finanszírozást. A magántóke-befektetések két fő csoportját a kockázatitóke-befektetések és a kivásárlások alkotják. Míg a kockázati tốkét a jelentős növekedést ígérő cégek kapják fejlődésük korai szakaszában, addig a kivásárlások általában érett cégek ellenôrzést biztosító tulajdoni hányadának felvásárlását takarják. A kivásárlások finanszírozása jelentős részben olyan hitellel történik, amelyre a felvásárlásra kerülő cég vagyona szolgál biztosítékul.

2 A kutatást a K 68471. számú OTKA-pályázat támogatta.
}

\section{Felhasznált irodalom}

Amess K. - Wright, M. (2007): The wage and employment effects of leveraged buyouts in the UK. International Journal of Economics and Business, 14. p. 179-195.

Amess, K. (2002): Management buyouts and firm-level productivity: Evidence from a panel of UK manufacturing firms. Scottish Journal of Political Economy, 49. p. 304-317.

Amess, K. (2003): The effects of manufacturing buyouts and on firm-level technical efficiency: Evidence from panel of UK machinery and equipment manufacturers. Journal of Industrial Economics, 51. p. 35-44.

Axelson, U. - Jenkinson, T. - Strömberg, P. - Weisbach, M. (2007): Leverage and pricing in buyouts: An empirical analysis. Swedish Institute for FinancialResearch conference on the economics of the private equity market. http://ssrn.com/abstract=1027127.
Bruining, H. (1992): Performance improvement postmanagement buyout. PhD diss., Earasmus University Rotterdam, Haveka

Bruner, R. - Eades, K. (1992): The crash of REVCO LBO: The hypothesis of inadequate capital. Financial Management, 21. p. 35-49.

Bull, I. (1989): Management performance in leveraged buyouts: An empirical analysis. Journal of Business, Venturing 3. p. 263-278.

Clarysse, B. - Knockaert, M. - Wright, M. (2009): Benchmarking UK Venture Capital to the US and Israel: What lessons can be learnd? May 2009, London: BVCA CMBOR (2008): Trends in management buyouts. Management buy-outs: Quarterly Review from the Centre for Management Buyout Research Spring. p. 1-30.

Cressy, R. - Munari, F. - Malipiero, A. (2007): Creative destruction: Evidence that buyouts cut jobs to raise returns. Working Paper, University of Birmingham

Davis, S. - Lerner, J. - Haltiwanger, J. - Miranda, J. Jarmin, R. (2008): Private equity and employment. In The global impact of private equity report 2008. Globalization of Alternative Investments, Working Papers Volume 1, ed. J. Lerner, A. Gurung, p. 43-64. New York: World Economic Forum

Davis, SJ. - Haltiwanger, J. - Jarmin, R. - Lerner, J. Miranda, J. (2009): Private Equity, Jobs and Productivity. The Global Economic Impact of Private Equity Report

Desbrieres, P. - Schatt, A. (2002): The impacts of LBOs on the performance of acquired firms: The French case. Journal of Business Finance and Accounting, 29. p. 695-729.

Economist (2009): Testing the model. Economist, July 7, p. 64.

EVCA (2005): Employment contribution to Private Equity and Venture Capital in Europe EVCA, November

EVCA (2009): EVCA Yearbook 2009, European Venture Capital and Private Equity Association, Brussells

EVCA - CMBOR (2008): The Impact of Private Equitybacked Buyouts on Employee Relations. Executive Summary, December, EVCA

Fencik, G. (2008): Is a Bubble Brewing in Private Equity Markets? CFA Institute, March

Financial Services Authority (2006): Private equity: A discussion of risk and regulatory engagement. Discussion Paper DP06/6. London: Financial Services Authority

Global Insight (2007): Venture Impact. The Economic Importance of Venture Capital Backed Companies to the U.S. Economy. Third Edition, NVCA

Gottschlag, O. (2007): Executive summary. European Parliament: Private Equity and Leveraged Buy-outs, Study, Policy Department Economic and Scientific Policy, IP/A/ECON/IC/2007-25.

Gurung, A. - Lerner, J. (2009): Executive Summary. The Global Economic Impact of Private Equity, January 2009, Globalization of Alternative Investments, World 
Economic Forum, Working Paper Volume 2, Geneva, Switzerland, World Economic Forum USA Inc., New York, USA

Hall, D. (2007): Methodological issues in estimating the impact of private equity buyouts on employment. May 2007, PSIRU, University of Greenwich

Harris, R. - Siegel, D.S. - Wright, M. (2005): Assessing the impact of management buyouts on economic efficiency: Plant-level evidence from the United Kingdom. Review of Economics and Statistics, 87. p. 148-153.

IFSL (2009): Private Equity 2009. IFSL Research, August, International Financial Services, London

ITUC (2007): Where the house always wins: Private equity, hedge funds and the new casino capitalism. Brussells: International Trade Union Confederation

Jensen, M.C. (2007): The Economic Case For Private Equity (and Some Concerns) - pdf of Keynote Slides, Negotiations, Organizations and Markets Research Papers, Harvard NOM research paper No. 07-02, Nov. 27

Kaplan, S. N. (1989): The effects of management buyouts on operations and value. Journal of Financial Economics, 24. p. 217-254.

Kaplan, S.N. - Stein, J. (1993): The evolution of buyout pricing in the 1980s. Quarterly Journal of Economics, 108. p. 313-357.

Kaplan, S.N. - Schoar, A. (2005): Private equity returns: Persistence and capital flows. Journal of Finance, 60. p. 1791-1823.

Kehoe, C. - Palter, R.N. (2009): The future of private equity. McKinsey on Finance, Number 31, Spring, McKinsey Company, p. 14.

Lerner, J. - Gurung, A. (2008): The Global Economic Impact of Private Equity Report 2008. World Economic Forum: Globalization of Alternative Investments, Working Papers Volume 1, Geneva, Switzerland, January

Lerner, J. - Schoar, A. - Wongsunwai, W. (2007): Smart institutions, foolish choices: The limited partner performance puzzle. Journal of Finance, 62. p. 731-764.

Lichtenberg, F.R. - Siegel, D. S. (1990): The effect of leveraged buyouts on productivity and related aspects of firm behavior. Journal of Financial Economics, 27. p. 165-194.

Malone, S. (1989): Characteristics of smaller company leveraged buyouts. Journal of Business Venturing, 4. p. 345-359.

Muscarella, C. - Vetsuypens, M. (1990): Efficiency and organizational structure: a study of reverse LBOs. Journal of Finance, 65. p. 1389-1413.

Nathusius, E. - Achleitner, A. - K.. (2009): Angels or Demons? Evidence on the Impact of Private Equity
Firms on Employment. CEFS Working paper Series 2009-10. http://ssrn.com/abstract=1420638

Nikoskelainen, E. - Wright, M. (2007): The impact of corporate governance mechanisms on value increase in leveraged buyouts. Journal of Corporate Finance, 13. p. 511-537.

NVCA. (2007): Venture Capital Five Year Performance Numbers Trend Positive in Q4 2006. NVCA, Thomson Financial, New York, April 30

Opler, T.C. (1992): Operating performance in leveraged buyouts. Financial Management, 21. p. 27-34.

PSE Group in European Parliament. (2007): Hedge funds and private equity: A critical analysis. Report of the PSE Group in European Parliament, Brussels, Parti Socialiste Européen

Singh, H. (1990): Management buyouts: Distinguishing characteristics and operating changes prior to public offering. Strategic Management Journal, 11. p. 111-129.

Strömberg, P. (2008): The new demography of private equity. In The Global Economic Impact of Private Equity Report 2008, Globalization of Alternative Investments, Working Papers Volume 1, ed. J. Lerner, A. Gurung, p. 3-26. New York: World Economic Forum

Strömberg, P. (2009): The Economic and Social Impact of Private Equity in Europe: Summary of research findings, July

Treasury Select Committee (2007): Private equity. Vol. 1. Report together with formal minutes. Tenth report of session 2006-7, HC567-1.

PEI: (2007): Private Equity Spotlight, 3, no. 5, May 1-15, Private Equity Intelligence

Walker, D. (2007): Guidelines for disclosure and tranparency in private equity. London: BVCA

Wright, M. - Coyne, J. (1985): Management buyouts. Beckenham: Croom Helm

Wright, M. - Gilligan, J. - Amess, K. (2009): The economic impact of private equity: what we know and what we would like to know. Venture Capital, 11. p. 1-22.

Wright, M. - Wilkinson, N. - Robbie, K. - Ennew, C. (1996/a): An analysis of failure in UK buy-outs and buy-ins. Managerial and Decision Economics, 17. p. 57-70.

Wright, M. - Wilson, N. - Robbie, K. (1996/b): The longer term effects of management-led buyouts. Journal of Entrepreneurial and Small Business Finance, 5. p. 213-234.

Wright, M. - Thompson, S. - Robbie, K. (1992): Venture capital and management-led leveraged buyouts: A European perspective. Journal of Business Venturing, 7, p. 47-71.

Cikk beérkezett: 2009. 9. hó

Lektori vélemény alapján véglegesítve: 2009 11. hó 